\title{
Revitalization of Service Quality to Gain Customer Satisfaction and Loyalty
}

\author{
Sher Akbar \\ School of Housing, Building and Planning, University Sains Malaysia, Malaysia \\ E-mail: sherakbar.rd07@student.usm.my \\ Ahmad Puad Mat Som \\ School of Housing, Building and Planning, University Sains Malaysia, Malaysia \\ E-mail: puadusm@gmail.com \\ Fazli Wadood \\ Graduate School of Management, University Sains Malaysia, Malaysia \\ E-mail: wadoodusm@yahoo.com \\ Naser Jamil Alzaidiyeen \\ School of Education, University Sains Malaysia, Malaysia \\ E-mail: Naser_jamel@yahoo.com
}

\begin{abstract}
This study examines the relationships between hotel service quality failure, customer perceived value, revitalization of service quality, customer satisfaction and loyalty in the hotel industry. A quantitative technique was used to collect data in this study. A number of findings were gathered through the survey of 105 hotel guests in Penang, Malaysia. The findings indicate that hotel revitalization of service quality had positive effects on customer loyalty, while perceived value and customer satisfaction were two significant variables that mediated the relationships between hotel service quality and customer loyalty. It was also found that hotel service quality had no profound and direct effects, but indirect positive effects on customer satisfaction. The recommendations for future research were also discussed in this study.
\end{abstract}

Keywords: Revitalization, Service quality, Customer satisfaction, Customer loyalty, Hotel industry

\section{Introduction}

Tourism is a fast growing industry in Malaysia, and there are different types of hotels serving guests and tourists. Many studies have been conducted in tourism organization related fields, but a few studies have been conducted in hotel service quality. Despite the importance and richness of the topic, few efforts have been made to investigate customers' responses to service failure and service revitalization and the impacts of those important variables on service organizations. This study is focusing on service failure and their revitalization based on the assumption that there is no single service system that is hundred percent perfect. Furthermore, it is impossible for an organization to provide a superlative and most excellent service and at the same time evade service failures. The fact is service delivery is performed by humans and can always carry errors and some weaknesses.

Service recovery which follows service failures provides possibilities for customers to evaluate the overall performance of a firm's recovery efforts. Excellent service recovery is a critical issue in today's service businesses. According to Fornell and Wernerfelt (1987), defensive marketing strategies such as customer retention through excellent service recovery will be an effective means to triumph in today's competitive market mainly because attracting new customers is getting difficult and more expensive than retaining existing customers. Rakstis (1992) argues its costs the average business $\$ 118.15$ to attract a new customer, whereas the figure is only $\$ 19.96$ to keep a current customer happy. Therefore, excellent service recovery is required to 
improve customer retention by the effective handling of the service failure situations (Berry \& Parasuraman, 1992).

Today, approximately three quarters of the gross national product comes from service businesses. It is known that service failures are inevitable, but unfortunately as mentioned earlier, very little empirical research examines service failures and service recoveries. Hoffman et al. (1995) argued that:

'Despite the importance of tracking and analyzing service failure and recovery strategies from a managerial perspective, only limited empirical research examining failures and recoveries has been conducted'.

Thus, the purpose of this paper is to examine the outcomes of service recovery and how much service recovery effects the satisfaction and loyalty of customers.

\section{Literature Review}

Service quality improvement becomes the most critical issue in the service industry since it can improve the productivity, decrease the cost, build customer satisfaction, and increase profits to firms (Marquardt, 1989; Power, 1992). The continual improvement of service quality is essential for the competitive advantage of a service business. Many service organizations are trying their best to improve service delivery and avoid failures, as Hart et al. (1990) claimed:

\section{'Mistakes are critical parts of every service. Hard as they try, even the best service companies cannot prevent the occasional late flights, burned steak, or missed delivery. The fact is, in services, often performed in the customer's presence, errors are inevitable'.}

Service providers are particularly prone to errors mainly due to the unique characteristics of service intangibility, perishability, heterogeneity, and inseparability (Berry \& Parasuraman 1992; Parasuraman, Zeithaml, \& Berry 1988). Among others, heterogeneity, which refers to the inability of service producer to provide consistent performance and quality, is one of the most prevalent factors that cause a service breakdown. Customer involvement in service production is another unique situation that causes service problems. As noted by numerous service researchers, many service delivery systems involve customers in the service production process (Langeard et al., 1981; Lovelock, 1991). For example, the performance of a medical doctor, to some extent, depends upon the information provided by the patient such as his or her medical history and the correct diagnose of symptoms. Customers themselves often participate in creating service product and affect the process, outcome of service, and service failures seem to be unavoidable (Stauss, 1993).

Parasuraman, Zeithaml, and Malhotra (2005) modified and refined the service quality scales and developed two sets of scales for measuring hotel service quality. One is called the Service Quality Scale (S-QUAL), consisting of 22 items to measure four dimensions: efficiency, system availability, fulfillment, and privacy. Another is called the Recovery Service Quality Scale (RecS-QUAL), consisting of 11 items to measure three dimensions: responsiveness, compensation, and contact. These scholars acknowledged that the RecS-QUAL scale is a subset scale of the S-QUAL scale. Nonetheless, the models need continuous validation and application to different types of hospitality market. It is contested that this model has difficulty in explaining how firms deal with service failure and how to turn dissatisfied customers into loyal customers. It is necessary to add service recovery as an important variable into the model to help explain how a firm can improve customer satisfaction through service failure solution to turn dissatisfied customers into loyal customers.

Service failures are inevitable due to the high 'people factor' of services in the hospitality business (Susskind, 2002). Service failure can accelerate customer dissatisfaction with the service provider, which could possibly lead to customer complaints. Hotel guests who are dissatisfied with the service phenomenon most likely will show the following four reactions: exit silently, spread a negative word-of mouth (WOM), voice their complaints to the operator, or continue to patronage the same property despite their dissatisfaction (Karande, Magnini, \& Tam, 2007; Susskind, 2002; Tax, Brown, \& Chandrashekaran, 1998). Service recovery refers to the actions taken by a firm in response to service failure (Zeithaml \& Bitner, 2003). Service failure often occurs when the customer's perceived service quality falls below customer expectations. For example, delivery and Web site design problems are two major types of service failure in online retailing (Holloway \& Beatty, 2003). Such failures may cause significant costs to the firm, such as losing customers and inducing negative words of mouth (Bitner, Brown, \& Meuter, 2000).

According to Hart et al. (1990), firms learn from experiences of service recovery when they may not be able to prevent service failure. Berry and Parasuraman (1992) believed that firms should not regard service failure as a 
problem but as an opportunity to create satisfied customers. Hence, recovery strategies have a dramatic impact on a firm's revenue and profitability (Tax \& Brown, 1998) as resolving customer problems has strong impacts on customer satisfaction and loyalty (Miller, Craighead, \& Karwan, 2000; Smith \& Bolton, 2002). Swanson and Kelley (2001) also found that customer behavioral intentions are more favorable when customers believe that firms consistently implement service recovery when failures occur. Furthermore, Robbins and Miller (2004) found that well-handled service recovery strongly affects customer loyalty.

Cronin and Taylor (1992) examined the causal relationships among service quality, customer satisfaction, and purchase intention. Each variable was measured by one item. There were 660 usable questionnaires randomly collected from four types of business customers in the southeastern United States: banking, pest control, dry cleaning, and fast food. The results of correlation analysis suggested that (1) service quality was an antecedent of consumer satisfaction, (2) service quality had less effect on purchase intentions than did consumer satisfaction, and (3) consumer satisfaction had a significant effect on purchase intentions. Dabholkar, Shepherd, and Thorpe (2000) also found that customer satisfaction strongly mediated the effect of service quality on behavioral intentions. The data used in their study were systematically and randomly collected from 397 churches. A test of discriminate validity revealed that the construct of service quality was different from the construct of customer satisfaction. The result of regression analysis in structural equation modeling supported their proposition that customer satisfaction had a stronger effect on behavioral intentions than service quality did (Dabholkar et al., 2000).

Service recovery is a positive step towards customer satisfaction and loyalty. Due to global competition, services providers are trying to facilitate such a service quality to customers which lead to uniqueness of selling proposition and to avoid product substitution. However, one study has shown that almost $70 \%$ of customers who change their service providers do not complain about price or product quality, but they complained about the indifferent attitude of their former providers (Bennington \& Cummane, 1998). Findings from the Jupiter Executive Survey (ES) revealed that a majority of $75 \%$ consumers expressed that the speedy response to customer service inquiries would affect their decision to make future purchases from a particular service industry (Cox, 2002). These consumers' responses indicate that service quality is one of the factors that influences customer satisfaction and retains customers in the competitive market.

\section{Methodology}

As mentioned earlier, the purpose of this study is to examine and explore the relationships among hotels' failures in service quality, recovery of service quality, customer satisfaction and customer loyalty, by adopting the $S-Q U A L$ and RecS-QUAL scales. A hypothesis to be tested is as below:

Hypothesis: Service revitalization has positive significance effect on customer satisfaction and loyalty.

A descriptive research was applied to gain an insight into the recovery of quality service failure offered by hotels with respect to the modified dimensions S-QUAL and RecS-QUAL developed by (Parasuraman et al., 2005). This study was carried out through a convenient survey in several four and five star hotels in Penang. The primary data was collected from customers' perception on revitalization of service quality of the particular hotels that they stayed. A total of 150 questionnaires were distributed but only 105 completed questionnaires were usable for analysis. This study measured five latent variables: hotel perceived service quality, recovery of service quality, perceived value, customer satisfaction, and customer loyalty.

\section{Figure 1 Variables of the study.}

These measurements were subject to reliability test and were found to be highly reliable. The reliability of scales used in this study was calculated by Cronbach's coefficient alpha. The coefficient alpha values exceeded the minimum standard of .7 (Nunnally \& Bernstein, 1994), providing good estimates of internal consistency reliability. As shown in Table 1, coefficient alpha values ranged from .79 to .95 for the eight dimensions of hotel service quality, from .86 to .91 for the three dimensions of hotel recovery service quality, and from .88 to .92 for other constructs. All constructs obtained an acceptable level of a coefficient alpha above .70, indicating that the scales used in this study were reliable. The estimates of standardized factor loadings were used to determine the convergent validity of scales. The minimum factor loading in the confirmatory factor analysis for items in this study was .79. Because each factor loading on each construct was more than .50, the convergent validity for each construct in this study was established (Hair, Anderson, Tatham, \& Black, 1998)

\section{Table 1 Reliability of Scales and Item-Construct Loadings}

\section{Empirical Findings}

Among the 105 respondents who completed the survey, it is evident that they were mostly international visitors. 
The respondents consisted of $61.9 \%$ males and $38.09 \%$ females, with an age range from 18 to 75 . The average age of the respondents was 32 years. Of all respondents, more than $90 \%$ completed varying degrees of higher education. The largest educational group was "four-year college graduate" (38.09\%), followed by "professional/graduate" group (36.19\%). The largest group of annual household income was between $\$ 60,000$ and $\$ 74,999(33.33 \%)$, with $66.64 \%$ of respondents' annual household income being less than $\$ 75,000$ and $23.8 \%$ of that being more than $\$ 75,000$. Further details about socio demographic characteristics of respondents are shown in Table 2.

\section{Table 2 Socio-demographic factor of the respondents}

To assess the representatives of the final data-producing sample with the target population and implications for external validity, the percentage difference in four demographic characteristics between the data-producing samples was conducted. For the characteristics of gender, the percentage difference was $23.81 \%$. For the characteristic of age, the percentage difference was $19 \%$ (under-representing those 45 and over). For the characteristic of education, the percentage difference was $25.71 \%$ (under-representing those with less than some college). For the characteristic of family income, the percentage difference was $9 \%$. The results indicated that the characteristics of the final data-producing sample in gender and family income had good representation, but not with the characteristics of age and education.

The results of the estimation of the hypothesized causal structure model indicated that the model fit well the sample $(\mathrm{GFI}=.92, \mathrm{TLI}=.94 ; \mathrm{NFI}=.95 ; \mathrm{CFI}=.96)$. The majority of the goodness-of-fit indices were satisfied with their relative recommended thresholds. Compared to the study of Parasuraman, Zeithaml, and Malhotra (2005), this study had a lower RMSEA value of .07 than that reported in their work. Therefore, no further modification was needed. A summary of the goodness-of-fit results is presented in Table 3 .

\section{Table 3 Goodness-of-Fit Results}

\section{Table 4 Regression Weights of the study variables}

\section{Table 5 Standardized Direct Effects, Indirect Effects, and Total Effects of the study variables}

As shown earlier, the regression weight of revitalization service quality to customer satisfaction $(t=-.80 ; p>.05)$ and failure service quality to customer satisfaction $(t=-1.33 ; p>.05)$ were not significant. This indicated that both perceived service quality and revitalization service quality had no significant direct effect on customer satisfaction. However, due to less standardization of data, it was difficult to make comparisons with each effect. Using standardized data allows this study to compare the relative effect of each exogenous latent variable on the endogenous latent variable (Hair, Anderson, Tatham, \& Black, 1998). The analyses of direct, indirect, and total effects, as presented in Table 5, may help understand how exogenous variables influenced endogenous variables. In Table 5, it indicated that two direct effects were not significant recovery service quality to customer satisfaction (-.074) and failure service quality to customer satisfaction (-.141). Four of six indirect effects were significant recovery service quality to perceived value (.356), recovery service quality to customer satisfaction (.175), service quality to customer satisfaction (.431), and perceived value to customer loyalty (.175). The results indicated that perceived value and customer satisfaction mediated the relationships among failure service quality, recovery service quality, and customer loyalty. Based on the goodness-of fit results and the results of analysis of direct, indirect, and total effects, the hypothesis in this study was supported.

\section{Conclusion}

From the results of study, it was shown that revitalization of the service quality has direct effect on customer loyalty, and indirect effect on customer value and satisfaction. There are two perspectives to explain the unpredicted findings. First, customers directly gain loyalty from the process of service revitalization. When they perceive higher service revitalization, they turn a loyal customer to specific service provider. Second, customers may expect to receive better services in the next transaction. When they expect better experience in the next transaction, they have higher satisfaction and higher loyalty.

This study hypothesized that perceived value and customer satisfaction mediates the relationships among failure service quality, revitalization, perceived value, and customer loyalty. The results of data analysis indicated that the hypothesis was supported. In another words, failure service quality and recovery service quality influence behavioral intentions via perceived value and satisfaction. The conclusion of this study support empirical findings of Cronin, Taylor (1992, 1994), Dabholkar, Shepherd, and Thorpe (2000). According to prior discussion, the hypothesized model modified the model presented in Figure 1. The modified model removed arrows representing the relationship among hotel recovery service quality, customer satisfaction, and perceived service quality and customer satisfaction. 
Perceived service failure to customers could improve recovery of service quality through several dimensions: responsiveness, perceived value, and compensation. Although hotel recovery service quality may not directly influence customer satisfaction, it may have an indirect effect on customer satisfaction via failure service quality. The most important strategy to retain loyal customers is improving quality of service recovery such as quick response during service failure. Customer satisfaction has direct effect on customers' behavioral intentions. This study was limited to examining the causal relationships among failure in service quality, perceived value, customer satisfaction, customer loyalty, and recovery service quality. In any future study, other significant variables, such as hotel image and customer behavior may be added into the hypothesized causal structural model. Moreover, future studies may use a different sampling method to collect data. Finally, theoretically, other variables like price perception, corporate image, switching cost and other factors influencing customer loyalty would have made the research model more robust and interesting.

\section{Acknowledgement}

This research has partially been supported by University Sains Malaysia's fellowship scheme and research grant.

\section{References}

Bell, C. R., \& Zemke, R. E. (1987). Service breakdown: the road to recovery. Management Review, 10, pp. 32-35.

Bennington, L., \& Cummane, J. (1998). Measuring service quality: A hybrid methodology. Total Quality Management, 9(6), pp. 395-405.

Berry, L. L., \& Parasuraman, A. (1992). Prescriptions for a service quality revolution in America. Organizational Dynamics, 20(4), pp. 5-15.

Bitner, M. J., Brown, S. W., \& Meuter, M. L. (2000). Technology infusion in service encounters. Journal of the Academy of Marketing Science, 28(1), pp. 138-149.

Byrne, B. M. (2001). Structural equation modeling with AMOS: Basic concepts, applications, and programming. Mahwah, NJ: Lawrence Erlbaum Associates, Inc.

Cronin, J. J., Jr., \& Taylor, S. A. (1994). SERVPERF versus SERVQUAL: Reconciling performance-based and perceptions-minus-expectations measurement of service quality. Journal of Marketing, 58(1), pp.125-131.

Fornell, C., \& Wernerfelt, B. (1987). Defensive marketing strategy by consumer complaint management: A theoretical analysis. Journal of Marketing Research, 24(4), pp. 337-346.

Hair, J. F., Jr., Anderson, R. E., Tatham, R. L., \& Black, W. C. (1998). Multivariate data analysis (5th ed.). Boston, MA: Pearson Education Inc.

Hart, C. W. L., Heskett, J. L., \& Sasser, W. E., J. (1990). The profitable art of service recovery. Harvard Business Review, 68(4), pp. 148-156.

Hoffman, K.D., Scott W. K and Holly M. R. (1995. Tracking Service Failures and Employee Recovery Efforts. Journal of Service Marketing. 9 (2), pp. 49-60.

Holloway, B. B., \& Beatty, S. E. (2003). Service failure in online retailing: A recovery opportunity. Journal of Service Research, 6(1), pp. 92-105.

Kerner, S. M. (2004). More broadband usage means more online spending. Retrieved June 10, 2009, [Online] Available: http://www.clickz.com/stats/sectors/broadband/article.php/3419281

Marquardt, I. A. (1989). The Link between Total Quaity Improvement and Market Orientation, in Guiry M. Quality and Customer Service: The Critical Focus for a Firm, Cambridge, Massachusetts: Marketing Science Institute Conference.

Millard, E. (2005). Online retail sales to surge in 2005. December 26, 2008, [Online] Available: http://www.cio-today.com/news.

Miller, P. (2001). Tuning in to electronics: Catalogers pursue consumer electronics industry. Catalog Age, 18(8), pp. 46-48.

Nunnally, J. C., \& Bernstein, I. H. (1994). Psychometric theory (3rd ed.). New York, NY: McGraw-Hill, Inc.

Parasuraman, A., Zeithaml, V. A., \& Berry, L. L. (1988). SERVQUAL: A multiple-item scale for measuring consumer perceptions of service quality. Journal of Retailing, 64(1), pp. 12-40.

Parasuraman, A., Zeithaml, V. A., \& Malhotra, A. (2005). E-S-QUAL: A multiple-item scale for assessing 
electronic service quality. Journal of Service Research, 7(10), pp. 1-21.

Power, C. (1992). Smart Selling: How Companies Are Winning over Today's Tougher Customer. Business Week, 46 (3).

Rakstis, J. (1992). Customer Service’s Big Payoff. Kiwanis Mangazine, Oct., pp. 32-5.

Reichheld, F. F., \& Sasser, W. E., J. (1990). Zero defections: Quality comes to services. Harvard Business Review, 68(5), pp. 105-111.

Robbins, T. L., \& Miller, J. L. (2004). Considering customer loyalty in developing service recovery strategies. Journal of Business Strategies, 21(2), pp. 95-109.

Sexton, R. S., Johnson, R. A., \& Hignite, M. A. (2002). Predicting Internet/e-commerce use. Internet Research, 12(5), pp. 402-410.

Stauss. A \& Bernd, C. (1993). Service Problem Deployment. Transformation of Problem Information into Problem Prevention Activities. International Journal of Service Industry Management. 4 (2), pp. 41-62.

Swanson, S. R., \& Kelley, S. W. (2001). Attributions and outcomes of the service recovery process. Journal of Marketing Theory and Practice, 9(4), pp. 50-65.

Tax, S. S., \& Brown, S. W. (1998). Recovering and learning from service failure. Sloan Management Review, 40(1), pp. 75-88.

Zeithaml, V. A., \& Bitner, M. J. (2003). Services marketing (3rd ed.). New York, NY: The McGraw-Hill Companies, Inc.

Zeithaml, V. A., Parasuraman, A., \& Malhotra, A. (2005). Service quality delivery through Web sites: A critical review of extant knowledge. Journal of Academy of Marketing Science, 30(4), pp. 362-375. 
Table 1. Reliability of Scales and Item-Construct Loadings

Construct / Factor / Item

Factor Loading

Service Failure

Efficiency (Cronbach's alpha $=.92)$

I feel difficult to deal with front office of this hotel. $\quad .87$

The services of this hotel is not convenient to me $\quad .91$

This hotel unable to complete a transaction quickly $\quad .89$

Having no well-organized information about service $\quad .94$

Keep no quick response to the problem $\quad .90$

Its not easy to find about the hotel service $\quad .86$

Its not easy to communicate with this hotel $\quad .91$

This hotel keep no well-organized equipments $\quad .86$

System Availability (Cronbach's alpha $=.91)$

Out of-date technology $\quad .88$

Les Online business $\quad .85$

No connection of Customer after leaving the hotel $\quad .88$

Recovery Service Quality (Rec S- QUAL)

Responsiveness (Cronbach's alpha $=90$

Provide with convenient options for accommodation $\quad .92$

Quickly and positive response to complain $\quad .88$

The service is dependable $\quad .90$

Perceived Value (Cronbach's alpha=.94)

Price

$\begin{array}{lr}\text { Overall value } & .95\end{array}$

Perceived control $\quad .92$

$\begin{array}{ll}\text { Perceived convenience } & .94\end{array}$

Customer Satisfaction (Cronbach's alpha $=.88$ )

Most recent experience

Compare with expectations

Compare with the ideal Web site

Customer Loyalty (Cronbach's alpha $=.93$ )

Positive word-of-mouth

Recommend to others

Encourage others to use

First choice for future 
Table 2. Socio-Demographic Characteristics of the Sample by Gender, Age, Education and Annual Household Income

\begin{tabular}{lcc}
\hline \multicolumn{1}{c}{ Demographic variables } & Frequency & Valid percentage \\
\hline Gender $(\mathrm{n}=105)$ & & \\
Male & 65 & $61.90 \%$ \\
Female & 40 & $38.09 \%$ \\
Age $^{\mathrm{a}}(\mathrm{n}=105)$ & & \\
$18-25$ & 10 & $9.52 \%$ \\
$26-35$ & 30 & $28.57 \%$ \\
$36-45$ & 35 & $33.33 \%$ \\
$46-55$ & 20 & $19.04 \%$ \\
56 or more & 10 & $9.52 \%$ \\
Education Scale (n $=105)$ & & \\
1. Professional/Graduate & 38 & $36.19 \%$ \\
2. Four-year college graduate & 40 & $38.09 \%$ \\
3. One to three years college & 17 & $16.19 \%$ \\
4. High school graduate & 10 & $9.52 \%$ \\
Annual Household Income $(\mathrm{n}=105)$ & & \\
Less than $\$ 30,000$ & 5 & $4.76 \%$ \\
\$30,000-\$ 44,999 & 10 & $9.52 \%$ \\
\$45,000-\$ 59,999 & 20 & $19.04 \%$ \\
\$ 60,000-\$ 74,999 & 35 & $33.33 \%$ \\
\$ 75,000-\$ 89,999 & 10 & $9.52 \%$ \\
\$ 90,000-\$104,999 & 5 & $4.76 \%$ \\
\$105,000-\$119,999 & 5 & $4.76 \%$ \\
\$120,000 or more & 15 & $14.28 \%$ \\
\hline
\end{tabular}

The average age was 33.33 years old, and the standard deviation is 10.5 .

Table 3. Goodness-of-Fit Results of the study

\begin{tabular}{lccc}
\hline \multicolumn{1}{c}{ Goodness-of-fit statistics } & & Values & $\begin{array}{c}\text { Desired range } \\
\text { of values for a } \\
\text { good fit }\end{array}$ \\
\hline $\begin{array}{l}\text { Absolute fit measures } \\
\text { Chi-square test }\end{array}$ & $\chi^{2}$ & 5.24 & $p>.05$ \\
& & $(p>.05)$ & \\
Degrees of freedom & Df & 3 & $\geq 0$ \\
Chi-square / degrees of freedom ratio & $\mathrm{X}^{2} / \mathrm{df}$ & 1.75 & 2 to 5 \\
Goodness of fit index & GFI & .92 & $>.90$ \\
Root mean square error of approximation & RMSEA & .08 & $<.08$ \\
& & & \\
Incremental fit measures & & & $>.90$ \\
Adjusted good-of-fit index & AGFI & .92 & $>.90$ \\
Tucker-Lewis index & TLI & .94 & $>.90$ \\
Normed fit index & NFI & .95 & $>.95$ \\
$\quad$ Comparative fit index & CFI & .96 & \\
\hline
\end{tabular}


Table 4. Regression Weights of the study variables

\begin{tabular}{|c|c|c|c|c|c|}
\hline & & $\begin{array}{c}\text { Un standardized } \\
B \text { coefficient }\end{array}$ & S.E. & $\begin{array}{c}\text { Standardized } \boldsymbol{\beta} \\
\text { coefficient }\end{array}$ & $t$-value \\
\hline Service Quality & $\begin{array}{l}\text { Recovery Service } \\
\text { Quality }\end{array}$ & 1.23 & .14 & .62 & $8.63 * *$ \\
\hline Perceived Value & $\leftarrow$ Service Quality & .20 & .03 & .56 & $7.31 * *$ \\
\hline $\begin{array}{r}\text { Customer } \\
\text { Satisfaction }\end{array}$ & $\leftarrow$ Perceived Value & .43 & .05 & .75 & $9.11 * *$ \\
\hline $\begin{array}{r}\text { Customer } \\
\text { Satisfaction }\end{array}$ & $\leftarrow$ Service Quality & -.03 & .02 & -.14 & -1.33 \\
\hline $\begin{array}{r}\text { Customer } \\
\text { Satisfaction }\end{array}$ & $\leftarrow \begin{array}{l}\text { Recovery Service } \\
\text { Quality }\end{array}$ & -.03 & .04 & .07 & -.80 \\
\hline $\begin{array}{r}\text { Customer } \\
\text { Loyalty }\end{array}$ & $\leftarrow \begin{array}{l}\text { Customer } \\
\text { Satisfaction }\end{array}$ & .25 & .07 & .23 & $3.82 * *$ \\
\hline $\begin{array}{r}\text { Customer } \\
\text { Loyalty }\end{array}$ & $\leftarrow \begin{array}{l}\text { Recovery Service } \\
\text { Quality }\end{array}$ & .30 & .03 & .69 & $11.48 * *$ \\
\hline
\end{tabular}

Table 5. Standardized Direct Effects, Indirect Effects, and Total Effects of the study variables

\begin{tabular}{|c|c|c|c|c|}
\hline & $\begin{array}{l}\text { Recovery } \\
\text { Service } \\
\text { Quality }\end{array}$ & $\begin{array}{l}\text { Service } \\
\text { Quality }\end{array}$ & $\begin{array}{c}\text { Perceived } \\
\text { Value }\end{array}$ & $\begin{array}{l}\text { Customer } \\
\text { Satisfaction }\end{array}$ \\
\hline \multicolumn{5}{|l|}{ Direct effects } \\
\hline Service quality & $.623 * *$ & & & \\
\hline Perceived value & & $.560 * *$ & & \\
\hline Customer satisfaction & -.074 & -.141 & $.750 * *$ & \\
\hline Customer loyalty & $.683 * *$ & & & $.231 * *$ \\
\hline \multicolumn{5}{|l|}{ Indirect effects } \\
\hline Perceived value & $.356^{* *}$ & & & \\
\hline Customer satisfaction & $.175^{*}$ & $.431 * *$ & & \\
\hline Customer loyalty & .024 & .064 & $.172 *$ & \\
\hline \multicolumn{5}{|l|}{ Total effects $^{\mathrm{a}}$} \\
\hline Service quality & $.631 * *$ & & & \\
\hline Perceived value & $.334 * *$ & $.560 * *$ & & \\
\hline Customer satisfaction & .104 & $.279 * *$ & $.750 * *$ & \\
\hline Customer loyalty & $.718 * *$ & .063 & $.172 *$ & $.235^{* *}$ \\
\hline
\end{tabular}

Note. $* p \leq .05 ; \quad * * p \leq .01$ 


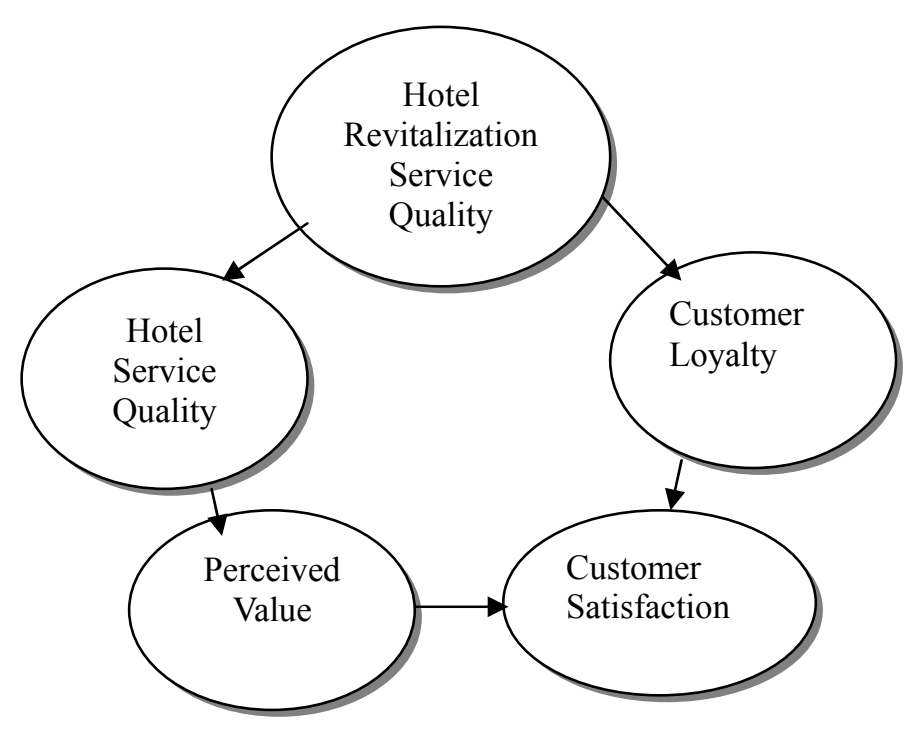

Figure 1. Variables of the study 